\title{
Aniversarios ignacianos \\ que recuerdan y comprometen
}

\author{
Revista Latinoamericana de Teología, \\ San Salvador, EI Salvador.
}

Comenzamos el oclavo afto de edición de la Revista Latinoamericana de Teologla. Coincide, como la mayoría de los lectores ya saben, con un afto en el cual los jesuilas recordamos el $\mathbf{5 0 0}$ aniversario del nacimiento de Ignacio de Loyola y el $\mathbf{4 5 0}$ de la fundación de la Compantía de Jesús.

No nos gustan los triunfalismos ni las nostalgias. No se trata de aprovechar estas conmemoraciones para hacer propaganda, ni tampoco de recordar por recordar. ¿Por qué, entonces, hacemos memoria ahora de estas fechas? Sencillamente porque creemos que Ignacio de Loyola y lo que con él comenzó ha contribuido y está contribuyendo en la historia del mundo durante los últimos cinco siglos; cinco siglos, por otra parte, tan decisivos para entender la situación de nuestros paises de América Latina.

Si el lema de la Companía de Jesús ha sido y sigue siendo Ad maiorem Dei gloriam, hay muchas sefiales que nos manifiestan que aquella ha intentado ir haciendo siempre una auténtica labor hermenéutica del mismo, para descubrir en cada nueva situación espacial y temporal cómo los jesuitas podlamos conseguir que efectivamente aumentase en el mundo la gloria de Dios: una gloria de Dios entendida en los primeros siglos de la Iglesia como "vida del ser humano" (la gloria de Dios es que el hombre viva, decia Ireneo) y entendida en nuestros últimos decenios aqui en nuestra Iglesia latinoamericana como "vida del pobre" (la gloria de Dios es el que el pobre viva, decía monseffor Romero).

Ejemplos típicos de lo anterior los tenemos en los muchos proyectos trazados por los jesuitas a través de la historia y que han resultado ser auténticos intentos de actualización para responder apostólicamente al reto planteado de la "mayor gloria de Dios". Entre ellos se pueden mencionar "los ritos chinos", "las reducciones del Paraguay" y, ya en nuestros días, la insistencia en la necesidad 
de promover con todas las fuerzas posibles y conjuntamente la fe y la justicia, como dentro y punto focal de toda nuestra evangelización, es decir, de nuestra transmisión de la buena noticia.

Con toda humildad, pues, la Revista Latinoamericana de Teología quiere contribuir a recordar, en este afto de conmemoraciones ignacianas, la interpelación y el reto que supone para la Companía de Jesús el seguir llevando en su título el nombre de Jesús, el proponer como lema de su misión el Ad maiorem Dei gloriam, el tener los Ejercicios Espirituales de san Ignacio cono el instrumento privilegiado de la espiritualidad jesuítica, el contar entre sus miembros a tantos testigos de la fe como el padre Pedro Arrupe (recientemente fallecido), como los mártires del 16 de noviembre de El Salvador y como tantos otros que han entregado sus vidas por anunciar y defender la buena noticia del reino de Dios preferentemente para los pobres.

Nuestro aporte consistirá en ir ofreciendo a lo largo de los próximos números de nuestra revista algunos arículos (en el presente número ya presentamos varios) que ayuden a profundizar, conocer mejor y actualizar la espiritualidad de Ignacio de Loyola, la historia del compromiso jesuítico con las causas justas, el ansia renovadora que aparece en muchos momentos de la vida de la Comparía de Jesús. 